\title{
HbA1c levels in individuals heterozygous for hemoglobin variants
}

\author{
Ricardo Silva Tavares $^{1}$, Fábio Oliveira de Souza ${ }^{1 *}$, Isabel Cristina Carvalho Medeiros Francescantonio², \\ Weslley Carvalho Soares ${ }^{1}$, Mauro Meira Mesquita ${ }^{3}$ \\ ${ }^{1}$ Undergraduate Degree in Biomedicine from Pontifícia Universidade Católica de Goiás (PUC Goiás), Goiânia, GO, Brazil \\ ${ }^{2} \mathrm{MD}$ and PhD Professor at the School of Medical, Pharmaceutical and Biomedical Sciences, PUC Goiás, Goiânia, GO, Brazil \\ ${ }^{3}$ MSc Professor at the School of Medical, Pharmaceutical and Biomedical Sciences, PUC Goiás, Goiânia, GO, Brazil
}

Study conducted at Laboratório Clínico da Pontifícia Universidade Católica de Goiás (PUC Goiás), Goiânia, GO, Brazil

Article received: $7 / 28 / 2016$ Accepted for publication: $10 / 17 / 2016$

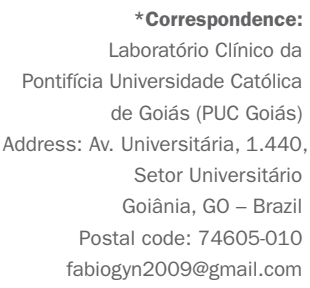

*Correspondence: Laboratório Clínico da Pontifícia Universidade Católica de Goiás (PUC Goiás)

Address: Av. Universitária, 1.440 Setor Universitário Goiânia, GO - Brazil Postal code: 74605-010 fabiogyn2009@gmail.com

\section{SUMMARY}

Objective: To evaluate the levels of glycated hemoglobin (HbA1c) in patients heterozygous for hemoglobin variants and compare the results of this test with those of a control group.

Method: This was an experimental study based on the comparison of HbA1c tests in two different populations, with a test group represented by individuals heterozygous for hemoglobin variants (AS and $\mathrm{AC}$ ) and a control group consisting of people with electrophoretic profile AA. The two populations were required to meet the following inclusion criteria: Normal levels of fasting glucose, hemoglobin, urea and triglycerides, bilirubin $>20 \mathrm{mg} / \mathrm{dL}$ and non-use of acetylsalicylic acid. 50 heterozygous subjects and 50 controls were evaluated between August 2013 and May 2014. The comparison of HbA1c levels between heterozygous individuals and control subjects was performed based on standard deviation, mean and G-Test.

Results: The study assessed a test group and a control group, both with 39 adults and 11 children. The mean among heterozygous adults for HbA1c was 5.0\%, while the control group showed a rate of 5.74\%. Heterozygous children presented mean $\mathrm{HbA} 1 \mathrm{c}$ at $5.11 \%$, while the controls were at $5.78 \%$. G-Test yielded $\mathrm{p}=0.93$ for children and $\mathrm{p}=0.89$ for adults.

Conclusion: Our study evaluated HbA1c using ion exchange chromatography resins, and the patients heterozygous for hemoglobin variants showed no significant difference from the control group.

Keywords: glycated hemoglobin A, ion exchange chromatography, hemoglobins.

\section{INTRODUCTION}

Glycated hemoglobin (HbA1c) is used to assess the efficacy of diabetes treatment and is a paramount control for better quality of life among patients. The test reveals the mean blood glucose in the last four months before the test, based on the turnover of hemoglobin, which lasts 120 days. ${ }^{1}$ Clinical data show that the mean level of blood glucose in the 20 to 30 days preceding blood sampling contributes around $50 \%$ of the end result of $\mathrm{HbA1c}$, while the mean level in the prior 90 to 120 days contributes only $10 \%$. Thus, this method can detect large variations in blood glucose. ${ }^{2,3}$

$\mathrm{HbA} 1 \mathrm{c}$ was defined as a diagnostic method for diabetes mellitus, with a threshold of $6.5 \%$ for adults. The test should be performed using a method that is certified by the National Glycohemoglobin Standardization Pro- gram (NGSP) and standardized or traceable to the Diabetes Control and Complications Trial (DCCT) reference. ${ }^{4}$

For the measurement of $\mathrm{HbA1c}$, it is desirable that laboratories use NGSP certified methods, and it is important to note that high-performance liquid chromatography (HPLC) is not the only method available for the measurement of HbA1c. Several other diagnostic sets that use non-HPLC methods are also certified. The following methods were also evaluated by the NGSP: turbidimetric immunoassay, electrophoresis, ion exchange chromatography and enzymatic assay. ${ }^{5-8}$

HbA1c has several advantages over fasting glycemia, including greater convenience, since fasting is not necessary, evidence suggesting greater pre-analytical stability, and fewer day-to-day disturbances during periods of stress and disease. ${ }^{4}$ 
For a reliable $\mathrm{HbA1c}$ result, some possible interferers must be considered, including the labile fraction and sample preservation. ${ }^{9}{ }^{10}$ In addition to the variables mentioned above, some factors such as hyperbilirubinemia, hypertriglyceridemia, hyperuremia, chronic alcoholism, chronic ingestion of salicylates and opiate dependence can significantly alter $\mathrm{HbA} 1 \mathrm{c}$ results, producing falsely increased results. ${ }^{2}$ False-low results are observed in the presence of large amounts of vitamins $C$ and $E$, which are described as inhibitory factors for hemoglobin glycation., 2,6,7,9,11,12

Hemoglobinopathies and hemoglobin variants are also interfering factors, the latter being characterized by changes in hemoglobin structure caused by differences in the amino acid sequence of globin chains. ${ }^{2,7,9}$

Hemoglobin $(\mathrm{Hb})$ is a spheroidal molecule, which is located inside the red blood cells and whose main function is the transport of oxygen to the tissues. ${ }^{13}$ Its structure is composed of four subunits formed by two pairs of identical polypeptide chains, called globins, each bound to a heme group. The hemoglobin profile of a normal adult contains about $97 \%$ of $\mathrm{HbA}$ (two $\alpha$-globin chains and two $\beta$-globin chains, represented as $\alpha 2 \beta 2$ ), $2 \%$ of $\mathrm{HbA} 2(\alpha 22)$ and $1 \%$ of fetal $\mathrm{Hb}(\mathrm{HbF}$, represented as $\alpha 2 \gamma 2)$, which is the predominant $\mathrm{Hb}$ during intrauterine life. ${ }^{10}$

HbA1c is a subtype derived from the binding of HbA1 by means of an irreversible non-enzymatic reaction between blood glucose and the $\mathrm{N}$-terminal amino acid valine of the beta chain. ${ }^{14}$

The change in hemoglobin levels observed in heterozygous individuals may interfere with test results, which is the case of HbA1c. ${ }^{15}$ Thus, our objective in the present study was to verify A1c levels in patients heterozygous for hemoglobin variants.

\section{Method}

This is an experimental study, based on the comparison of HbA1c test results from two different populations: a test group represented by individuals heterozygous for hemoglobin variants (AS and AC) and a control group consisting of people with electrophoretic profile AA confirmed by hemoglobin electrophoresis at alkaline $\mathrm{pH}$. Both populations were required to meet the inclusion criteria: Normal levels of fasting glucose, hemoglobin, urea and triglycerides, bilirubin $>20 \mathrm{mg} / \mathrm{dL}$, and non-use of acetylsalicylic acid (ASA). All of the above factors, if changed, can trigger falsely high or low results. 2,6,7,9,11,12

In addition to the HbA1c test, other tests were performed in the two populations to contribute to the interpretation of $\mathrm{HbA1c}$, such as: fasting blood glucose and blood counts, as well as tests to identify possible interferers: urea and triglycerides. Still assessing interferences, we checked if the samples were icteric, as bilirubin levels above $20 \mathrm{mg} / \mathrm{dL}$ can cause falsely high $\mathrm{HbA1c}$ results. We paid special attention to ascorbic acid, which influences the assessment of $\mathrm{HbA1c}$. It is a volatile compound and, after gathering sampling, requires a period of 90 minutes to be separated from the rest of the blood sample and proceed to dosing., 2,7,

The heterozygous participants were selected from the Clinical Laboratory (LAC, in the Portuguese acronym) database at Pontifícia Universidade Católica de Goiás (PUC Goiás), and invited to participate in the research. A Free and Informed Consent Form with the Code of Approval by the Ethics Committee (no. 4.1.1.00-0 PUC Goiás) was promptly presented to them.

Whole blood samples were collected in three tubes stored and distributed as follows: a tube containing EDTA (ethylenediaminetetraacetic acid) for blood counts and HbA1c; a fluoride tube for blood glucose dosing; and a tube for serum separation and dosing of triglycerides and urea.

HbA1c was measured using a column method of ion-exchange resins to separate $\mathrm{HbA1c}$, which was subsequently read on a CELM (Cia. Equipadora de Laboratórios Modernos) spectrophotometer, with the aid of the HbA1c dosing kit Gold Analisa Diagnóstica Ltda ${ }^{\odot}$ (Lot: 30031).

HbA1c levels read by column chromatography are equivalent to those obtained with HPLC, which is certified by the NGSP, and can be converted to standard HPLC method from the International Federation of Clinical Chemistry (IFCC) using the formula: $\operatorname{IFCC}=(10.93 \times$ NGSP)-23.50. ${ }^{16,17}$

Blood glucose levels were measured using a glucose oxidase method, ELITechGroup ${ }^{\circ}$ (Lot: 13-0096), while the blood counts were assessed with Sysmex ${ }^{\circ}$ XE-2100 automated hematology analyzer.

To eliminate the interferers from the HbA1c test, urea, triglycerides and bilirubin were dosed in the patients' serum. An enzymatic colorimetric test was used to estimate serum urea and bilirubin, and peroxidase-oxidase for the analysis of triglycerides, whose dosages were measured using Selectra ${ }^{\circledR}$ XL - Vitalab. In order to validate the fasting blood glucose, urea, triglycerides and bilirubin tests, three control sera were used, namely positive and normal controls branded ELITechGroup ${ }^{\circ}$ (Lot: $5564 \mathrm{~A}$ and Lot: $3575 \mathrm{~B}$, respectively) and the control serum of the $\mathrm{Na}$ tional Program of Quality Control (PNCQ) (Lot: 3575).

The study divided groups by age group according to Ministry of Health criteria: children and adolescents aged $<20$ years, adults aged 20 to 60 years. ${ }^{18}$

We evaluated 50 individuals heterozygous for hemoglobin variants and 50 controls from August 2013 to May 2014. 
Data were tabulated using statistical software, Microsoft Excel $^{\circledR}$ and GraphPad Software, Inc., version Prisma 6. Comparison of HbA1c levels between individuals heterozygous for hemoglobin variants and controls with no change in hemoglobin structure was performed based on standard deviation, mean and G-Test.

\section{RESULTS}

We analyzed 50 patients heterozygous for hemoglobin variants with normal blood glucose levels, of which 23 were male, representing $46 \%$ of the study population, and 27 were female, totaling $54 \%$. Of the total $50,16 \%$ are AC and the remaining $84 \%$ are AS.

Dividing the group by age, we found 39 adults with a mean age of 34.6 years ( $21 \pm 38$ years) and 11 children and adolescents with a mean age of 5.9 years, ranging from 1 to 13 years. In this group, no interferer was observed, as described in Table 1.

$\begin{aligned} & \text { TABLE } 1 \text { Assessment of interferers in a heterozygous } \\
& \text { population. }\end{aligned}$
\begin{tabular}{lllll} 
Tests & Mean & $\begin{array}{l}\text { Minimum } \\
\text { value }\end{array}$ & $\begin{array}{l}\text { Maximum } \\
\text { value }\end{array}$ & $\begin{array}{l}\text { Reference } \\
\text { value }\end{array}$ \\
\hline Urea & $27 \mathrm{mg} / \mathrm{dL}$ & $17 \mathrm{mg} / \mathrm{dL}$ & $39 \mathrm{mg} / \mathrm{dL}$ & $15-40 \mathrm{mg} / \mathrm{dL}$ \\
\hline Triglycerides & $113 \mathrm{mg} / \mathrm{dL}$ & $80 \mathrm{mg} / \mathrm{dL}$ & $143 \mathrm{mg} / \mathrm{dL}$ & $<150 \mathrm{mg} / \mathrm{dL}$ \\
\hline Total bilirubin & $0.9 \mathrm{mg} / \mathrm{dL}$ & $0.6 \mathrm{mg} / \mathrm{dL}$ & $1.2 \mathrm{mg} / \mathrm{dL}$ & $\leq 1.2 \mathrm{mg} / \mathrm{dL}$ \\
\hline Source: Clinical Laboratory at PUC Goiás.
\end{tabular}

The mean values of HbA1c in heterozygous children were at $5.11 \%$, with a minimum of $3.9 \%$ and maximum of $5.97 \%$. The mean fasting glucose in this group was $89.56 \mathrm{mg} / \mathrm{dL}$, ranging from a minimum of $75 \mathrm{mg} / \mathrm{dL}$ to a maximum of $97 \mathrm{mg} / \mathrm{dL}$, while mean hemoglobin was $12.9 \mathrm{~g} / \mathrm{dL}$, ranging from $12.1 \mathrm{~g} / \mathrm{dL}$ and $14 \mathrm{~g} / \mathrm{dL}$.

The mean A1c of heterozygous adults was close to the values found for children, at $5.0 \%$, ranging from a minimum of $3.1 \%$ to a maximum of $6.9 \%$. As for mean fasting blood glucose, the adult population presented $84 \mathrm{mg} / \mathrm{dL}$, ranging from a minimum of $69 \mathrm{mg} / \mathrm{dL}$ to a maximum of $97 \mathrm{mg} / \mathrm{dL}$. Mean hemoglobin was at $13.8 \mathrm{~g} / \mathrm{dL}$, ranging from $12.3 \mathrm{~g} / \mathrm{dL}$ to $15.8 \mathrm{~g} / \mathrm{dL}$.

In order to compare the data, we analyzed the same tests in 50 patients without heterozygosity for hemoglobinopathies, with normal glycemic levels, of which $71.4 \%$ were female. This group included 11 children and adolescents, with a mean age of 10 years ( $6 \pm 14$ years). The following results were found in this class: HbA1c $5.78 \%$, fasting blood glucose $78.8 \mathrm{mg} / \mathrm{dL}$ and hemoglobin $14 \mathrm{~g} / \mathrm{dL}$.

With regard to the adult control population, 39 people with mean age of 45 years ( $22 \pm 37$ years) were analyzed. We found in this group the following mean test results: HbA1c $5.84 \%$, ranging from $4.1 \%$ to a maximum of $6.9 \%$, fasting blood glucose at $89.3 \mathrm{mg} / \mathrm{dL}$, ranging from $60 \mathrm{mg} / \mathrm{dL}$ to $99 \mathrm{mg} / \mathrm{dL}$, and mean hemoglobin at $13.6 \mathrm{~g} / \mathrm{dL}$, ranging from a minimum of $12 \mathrm{~g} / \mathrm{dL}$ to a maximum of $15.7 \mathrm{~g} / \mathrm{dL}$.

HbA1c standard deviation of the children was then calculated, reaching the result of 0.40 in the control group and 0.75 in the test group. The standard deviation from the adult test population was also calculated, which was 1.09 and the control was 0.57 .

The value of the G-test was also determined, representing the result of $\mathrm{HbA} 1 \mathrm{c}$ in the normal group compared to the altered group, reaching $\mathrm{p}=0.93$ for children and $\mathrm{p}=0.89$ for adults (Figures 1 and 2 ).

Of the 50 heterozygous individuals, ten had results below the lower limit of $4 \%$. Of these, eight were adults and two were children, of whom nine were female. The electrophoretic pattern of this group was verified and eight fit the AS profile, while two were AC.

\section{Discussion}

This study showed significant similarity with the findings of Menezes et al., ${ }^{19}$ whose comparative inferential analysis of HbA1c was: AA, AS, AC and SS obtained from blood samples from 150 participants, including diabetics, was not significant, the same being observed in our study with 100 subjects who had normal glycemic levels.

Yedla, Kuchay and Mithal ${ }^{20}$ evaluated the levels of fasting blood glucose, postprandial blood glucose, fructosamine and $\mathrm{HbA} 1 \mathrm{c}$ (immunoassay technique) of a diabetic patient, resulting in higher levels of fasting blood glucose, postprandial blood glucose and fructosamine, but not HbA1c, which remained normal. They concluded that the result was underestimated, and a different technique should be performed for this type of examination.

According to the study, ion exchange chromatography (HPLC) as a method used to measure HbA1c is not influenced by heterozygous hemoglobinopathies, as Copeland et al. ${ }^{21}$ report that some methodologies may have interference from heterozygous hemoglobins.

In a study by Camargo and Gross, ${ }^{22}$ the authors analyzed more than 25,000 samples and found patients heterozygous for $\mathrm{HbS}, \mathrm{HbC}$ or $\mathrm{HbD}$, noting that the presence of a hemoglobin variant may yield lower (false) results. However, anemia is also a source of negative interference. The hematological status should be considered for the correct interpretation of $\mathrm{GHb}$ results.

Despite cation exchange, HPLC is the reference method, and the presence of hemoglobin variants may interfere with levels of $\mathrm{HbA1c}$, yielding false high or low levels 


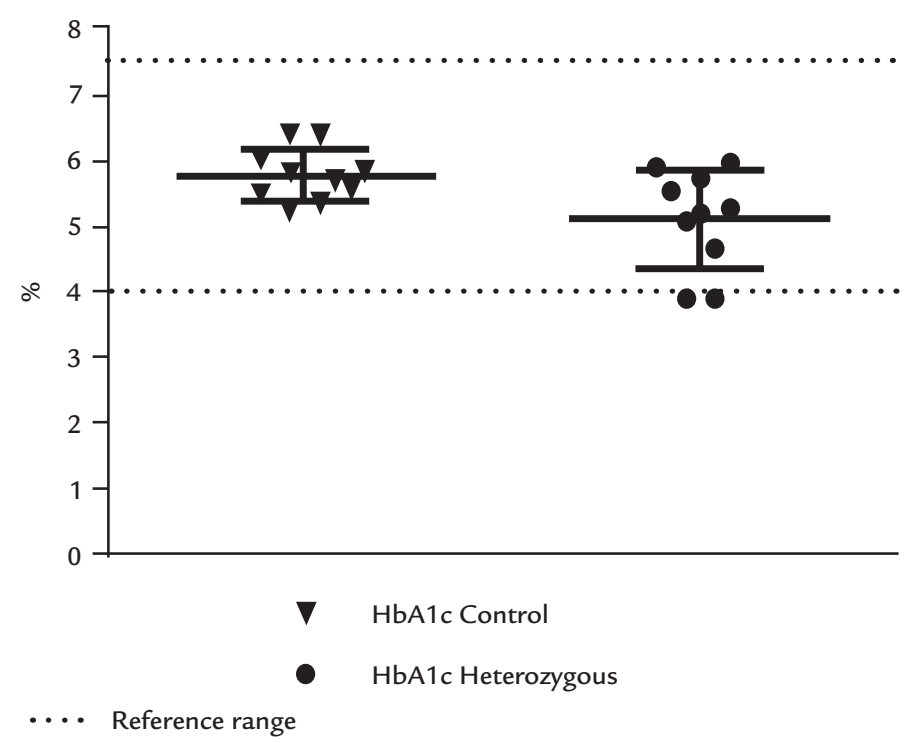

FIGURE 1 HbA1c comparison between control and heterozygous children.

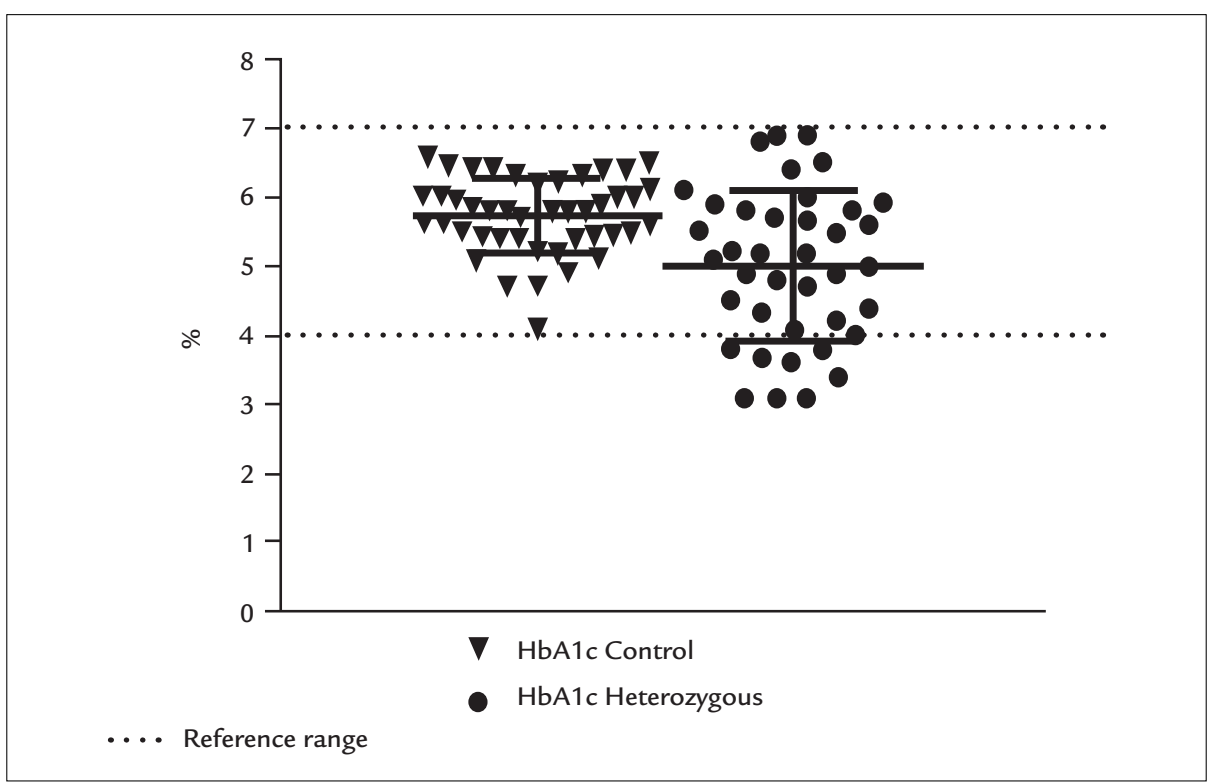

FIGURE 2 HbA1c comparison between control and heterozygous adults.

when the hemoglobin variant or its glycosylated form cannot be separated from hemoglobin A or HbA1c. ${ }^{23,24}$ In contrast, heterozygous hemoglobin $\mathrm{S}$ and $\mathrm{C}$ samples did not affect the assay. ${ }^{25}$

Not only hemoglobinopathies, including thalassemia syndromes, but also factors that affect red blood cell survival, age, uremia, hyperbilirubinemia and iron deficiency can affect the results of HbA1c tests. Racial and ethnic differences, genetic variation in hemoglobin glycation and assay methodology may also influence the results. ${ }^{26}$
New methods are being developed, such as mass spectrometry, which is based on the suppression of fluorescence of a boron eosin in acid solution, and shows minimal interference of the hemoglobin variants. ${ }^{27-30}$ Despite these valuable attributes, cost of equipment and complexity of the operation limit its use. ${ }^{31}$

According to studies, the presence of genetic variants of hemoglobin under heterozygous conditions may interfere with the measurement of $\mathrm{HbA1c}$, resulting in falsely high or decreased values, depending on the type of test used. 
Dosage of HbA1c does not apply in homozygous conditions to anomalous hemoglobins under any method, because, in these cases, hemoglobin A is practically absent. However, when an interfering hemoglobin variant is visualized or suspected, samples should be analyzed using an alternative method. In such cases, tests such as fructosamine and/or glycated albumin may be useful.,21,31

Bouzid et al. ${ }^{32}$ suggest that laboratory professionals add a footnote that reads: "Quantification of $\mathrm{HbA1c}$ was not possible using this method due to the presence of homozygous $\mathrm{HbS}$ or $\mathrm{HbC}$ variants or heterozygous SC compounds. We suggest fructosamine or another alternative." This would provide the physician with the information needed to properly manage these diabetic patients.

Lower levels of hemoglobin affect A1c measurement and, since women have lower hemoglobin levels than men, the $\mathrm{A} 1 \mathrm{c}$ result will suffer interference and the reference value should be different. ${ }^{33}$

\section{Conclusion}

Our study evaluated HbA1c using ion exchange chromatography, and the patients heterozygous for hemoglobin variants did not present a significant difference compared to the control group.

Based on the results of this study, members of the medical community should consider an assessment of laboratory results due to the differences in method employed for diagnostic support. When assessing laboratory results, the interpretation must include patient history, which may contain data related to the ethnic and socioeconomic characteristics of that specific population.

\section{Resumo}

Dosagem de hemoglobina glicada em heterozigotos para hemoglobinas variantes

Objetivo: Avaliar os níveis de hemoglobina glicada em pacientes heterozigotos para hemoglobinas variantes e comparar os resultados deste exame com grupo controle. Método: Trata-se de um estudo experimental, baseado na comparação do exame de hemoglobina glicada de duas populações diferentes, sendo um grupo teste, representado por indivíduos heterozigóticos para hemoglobinas variantes (AS e AC) e um grupo controle, constituído por pessoas com perfil eletroforético AA. As duas populações verificadas devem obedecer ao critério de inclusão: glicemia de jejum, hemoglobina, ureia e triglicérides normais, bilirrubina $>20 \mathrm{mg} / \mathrm{dL}$ e não fazer uso de ácido acetilsalicílico. Foram avaliados 50 indivíduos heterozigotos e
50 controles no período de agosto de 2013 a maio de 2014 . A comparação dos valores de hemoglobina glicada entre indivíduos heterozigóticos e controle foi realizada por meio do desvio padrão, média e teste $\mathrm{G}$.

Resultados: $\mathrm{O}$ estudo analisou um grupo teste e um grupo controle, ambos com 39 adultos e 11 crianças. A média dos adultos heterozigotos para $\mathrm{HbA1c}$ foi de $5,0 \%$, o grupo controle apresentou índice de 5,7\%. Já as crianças heterozigóticas obtiveram média de HbA1c de 5,11\%, enquanto as normais apresentaram valores médios de $5,78 \%$. O valor do teste $G$ foi de $\mathrm{p}=0,9$ para crianças e $\mathrm{p}=0,89$ para adultos.

Conclusão: Este estudo avaliou HbA1c pela metodologia de cromatografia de coluna com resinas de troca iônica, em que pacientes com heterozigoses para hemoglobinas variantes não apresentaram uma diferença significativa em relação ao grupo controle.

Palavras-chave: hemoglobina A glicosilada, cromatografia por troca iônica, hemoglobinas.

\section{References}

1. Suso K, Engroff P, Luísa E, Moriguchi Y, Carli G, Marrone FB. Prevalência de diabetes mellitus e correlação entre testes de glicemia em pacientes idosos atendidos no ambulatório do Instituto de Geriatria e Gerontologia. Rev Bras Anal Clin. 2011; 43(2):155-9.

2. Pimazoni Netto A, Andriolo A, Fraige Filho IF, Tambascia M, Gomes MB Melo M, et al. Atualização sobre hemoglobina glicada (HbA1c) para avaliação do controle glicêmico e para diagnóstico do diabetes: aspectos clínicos e laboratoriais. J Bras Patol Med Lab. 2009; 45(1):31-48.

3. Camargo JL, Gross JL. Glico-hemoglobina (HbA1c): aspectos clínicos e analíticos. Arq Bras Endocrinol Metab. 2004; 48(4):451-63.

4. American Diabetes Association (ADA). Standards of medical care in diabetes - 2014. Diabetes Care. 2014; 37(Suppl 1):S14-80.

5. Grupo Interdisciplinar de Padronização da Hemoglobina Glicada (A1C). Hemoglobina glicada. Posicionamento Oficial (versão 2003). A importância da hemoglobina glicada (A1C) para a avaliação do controle glicêmico em pacientes com diabetes mellitus: aspectos clínicos e laboratoriais [cited 2008 Nov 21]. Available from: http://www.sbpc.org.br/profissional/noticia.diverso.php?id=8\&tp=3.

6. Grupo Interdisciplinar de Padronização da Hemoglobina Glicada (A1C) Posicionamento Oficial (versão 2009). Atualização sobre hemoglobina glicada (A1C) para avaliação do controle glicêmico e para diagnóstico do diabetes: aspectos clínicos e laboratoriais [cited 2016 Jun 30]. Available from: www.sbpc.org.br/upload/conteudo/320110603170201.pdf.

7. National Glycohemoglobin Standardization Program. IFCC Padronização de HbA1c. 2010 [cited 2016 Jun 30]. Available from: http://www.ngsp.org/ifcc.asp.

8. Khuu HM, Robinson CA, Goolsby K, Hardy RW, Konrad RJ. Evaluation of a fully automated high-performace liquid chromatography assay for hemoglobin A1C. Arch Pathol Lab Med. 1999; 123(9):763-7.

9. Sacks DB, Bruns DE, Goldstein DE, Maclaren NK, McDonald JM, Parrott $\mathrm{M}$. Guidelines and recomendations for laboratopry analysis in the diagnosis and management of diabetes mellitus. Clin Chem J. 2002; 48(3):436-72.

10. Sacks DB, Burtis CA, Ashwood ER, Bruns DE. Textbook of clinical chemistry and molecular diagnostics. St Louis: Elsevier Saunders; 2006. p. 837-901.

11. Sumita NM, Andriolo A. Importância da hemoglobina glicada no controle do diabetes mellitus e na avaliação de risco das complicações crônicas. J Bras Patol Med Lab. 2008; 44(3):169-74.

12. Weykamp CW, Penders TJ, Muskiet FA, van der Slik W. Influence of hemoglobin variants and derivatives on glycohemoglobin determinations, as investigated by 102 laboratories using 16 methods. Clin Chem. 1993; 39(8):1717-23. 
13. Schechter A. Hemoglobin research and the origins of molecular medicine. Blood. 2008; 112(10):3927-38

14. Tran H, Silva D, Petrovsky N. Case study: potential pitfalls of using hemoglobin Alc as the sole measure of glycemic control. Clin Diabetes. 2004; 22(3):141-3.

15. Sacks DB, Burtis CA, Ashwood ER, editors. Tietz textbook of clinical chemistry. Philadelphia: W. B. Saunders; 1999. p. 750-808.

16. Hanas R, John WG; International HbA1c Consensus Committee. 2013 Update on the worldwide standardization of the hemoglobin A1c measurement. Pediatr Diabetes. 2014; 15(3):e1-2.

17. Hoelzel W, Weykamp C, Jeppsson J, Miedema K, Barr JR, Goodall I, et al.; IFCC Working Group on HbA1c Standardization. IFCC reference system for measurement of hemoglobin A1c in human blood and the national standardization schemes in the United States, Japan, and Sweden: a method-comparison study. Clin Chem. 2004; 50(1):166-74.

18. Secretaria de Atenção à Saude, Departamento de Atenção. Orientações para a coleta e análise de dados antropométricos em serviços de saúde. Brasília; 2011. p. 76.

19. Menezes MGS, Couto FD, Junior LSS, Adôrno EV, Barbosa CG, Gonçalves MS, et al. Determinação de HbA1c por CLAE: interferência de variantes de hemoglobinas S e C e alta concentração de HbF. J Bras Patol Med Lab. 2012; 48(5):337-44

20. Yedla N, Kuchay MS, Mithal A. Hemoglobin E disease and glycosylated hemoglobin. Indian J Endocrinol Metab. 2015; 19(5):683-5.

21. Copeland KC, Silverstein J, Moore KR, Prazar GE, Raymer T, Shiffman RN, et al. Al E. Management of newly diagnosed type 2 diabetes mellitus (T2DM) in children and adolescents. Pediatrics. 2013; 131(2):364-82.

22. Camargo JL, Gross JL. Conditions associated with very low values of glycohaemoglobin measured by an HPLC method. J Clin Pathol. 2004; 57(4):346-9.
23. Saw S, Loh TP, Yin C, Sethi SK. Identification of hemoglobin variants in samples received for glycated hemoglobin testing. Clin Chim Acta. 2013; 415:173-5.

24. Bry L, Chen PC, Sacks DB. Effects of hemoglobin variants and chemically modified derivatives on assays for glycohemoglobin. Clin Chem. 2001; 47(2):153-63

25. Behan KJ, Storey NM, Lee HK. Reporting variant hemoglobins discovered during hemoglobin A1c analysis - common practices in clinical laboratories. Clin Chim Acta. 2009; 406(1-2):124-8.

26. Herman WH, Cohen RM. Racial and ethnic differences in the relationship between $\mathrm{HbA} 1 \mathrm{c}$ and blood glucose: implications for the diagnosis of diabetes. J Clin Endocrinol Metab. 2012; 97(4):1067-72.

27. American Diabetes Association (ADA). Standards of medical care in diabetes--2011. Diabetes Care. 2011;34(Suppl 1):S11-61.

28. Nakanishi T, Miyazaki A, Iguchi K, Shimizu A. Effect of hemoglobin variants on routine glycohemoglobin measurements assessed by a mass spectrometric method. Clin Chem. 2000; 46(10):1689-92.

29. Blincko S, Anzetse J, Edwards R. Measurement of glycated haemoglobin in whole blood by a novel fluorescence quenching assay. Ann Clin Biochem. 2000; 37(Pt 4):492-7.

30. Schnedl WJ, Liebminger A, Roller RE, Lipp RW, Krejs GJ. Hemoglobin variants and determination of glycated hemoglobin (HbA1c). Diabetes Metab Res Rev. 2001; 17(2):94-8.

31. Sacks DB, Burtis CA, Ashwood ER, Bruns DE, editors. Tietz textbook of clinical chemistry and molecular diagnostics. St. Louis: Elsevier; 2012. p. 1415-56.

32. Bouzid K, Ahmed HB, Kalai E, Blibeche S, Couque N, Khiari K, et al. Prevalence of hemoglobin variants in a diabetic population at high risk of hemoglobinopathies and optimization of HbA1c monitoring by incorporating HPLC in the laboratory workup. Libyan J Med. 2014; 9:25768.

33. Faillace R. Hemograma: manual de interpretação. 4. ed. Porto Alegre: Artmed; 2003. p. 14-37. 